\title{
Pimelodus pintado (Siluriformes: Pimelodidae), a new species of catfish from affluent rivers of Laguna Merín, Uruguay, South America
}

\author{
María de las Mercedes AzPelicueta \\ Division Zoología Vertebrados, Museo de La Plata, Paseo del Bosque, 1900 La Plata, ARGENTINA, Email: azpeli@ciudad.com.ar
}

JOHN G. LUNDBERG

Department of Ichthyology, Academy of Natural Sciences, 1900 Benjamin Franklin Parkway, Philadelphia, PA 19103 USA, Email: lundberg@ansp.org

\section{MARCELO LOUREIRO}

Zoología Vertebrados, Facultad de Ciencias, Iguá 4438, Montevideo, URUGUAY, Email: mapy@fcien.edu.uy

\begin{abstract}
We describe a new species of pimelodid catfish belonging to the genus Pimelodus from the Cebollatí, Tacuarí and Yaguarón rivers emptying into the Laguna Merín, Uruguay. Pimelodus pintado $\mathbf{n}$. sp. is distinguished from congeners by the combination of its densely spotted pigmentation pattern with many small dots irregularly placed over flanks, head and all fins, and, when fresh, metallic golden background color, plus thick striated lips with prominent rictal folds, long snout, prominent upper jaw, anterior naris far from snout margin, narrow premaxillary tooth bands with rounded posterolateral corners, toothless prevomer and 22-26 gill rakers on first branchial arch. Pimelodus pintado is compared to other spotted species of Pimelodus including $P$. maculatus, $P$. heraldoi, $P$. absconditus, $P$. microstoma, $P$. mysteriosus, $P$. paranaensis, $P$. platicirris, $P$. ortmanni, $P$. britskii, P. fur, P. grosskopfii, P. navarroi, P. coprophagus and P. punctatus.
\end{abstract}

New taxon: Pimelodus pintado Azpelicueta, Lundberg and Loureiro

\section{INTRODUCTION}

The type species of the taxonomically challenging genus Pimelodus is $P$. maculatus LaCepède 1803, a boldly spotted catfish described from the lower Paraná River and ranging widely throughout that basin (Ringuelet et al., 1967). Populations of Pimelodus with spotted pigmentation from other Atlantic slope rivers including the São Francisco River (Britski et al., 1984) are often identified as $P$. maculatus. Some of these are, however, sufficiently divergent to be recognized as distinct species. In fact, several other weakly to strongly maculated but otherwise distinct species of Pimelodus occur in the Paraná or São Francisco rivers including some recently described: P. absconditus Azpelicueta, 1995, P. britskii Gravello and Shibatta, 2007, P. fur (Lütken 1874), P. heraldoi Azpelicueta, 2001, P. microstoma Steindachner, 1877 (see Ribeiro and Lucena, 2007), P. mysteriosus Azpelicueta, 1998, P. ortmanni Haseman, 1911, P. paranaensis Britski and Langeani, 1988, P. platicirris Borodin, 1927, and $P$. pohli Ribeiro and Lucena, 2006.

In this paper we describe a new and strikinglyspotted species of Pimelodus from the Cebollatí, Tacuarí and Yaguarón rivers in Uruguay that empty into Laguna
Merín (Fig. 1). The first specimens of the new species were detected in 1997 by one of us (MMA) in the collection of the Museu de Ciências e Tecnologia, Porto Alegre, and later at the Academy of Natural Sciences, Philadelphia and in a loan of Uruguayan Pimelodus from the Naturhistoriska Riksmuseet, Stockholm. Subsequent collecting in Uruguay conducted by MMA and ML yielded several additional specimens reported herein.

The Merín and dos Patos lagoons constitute the most important $\left(>6,000 \mathrm{~km}^{2}\right)$ coastal, fresh to brackish water system in southern South America. The lagoons are situated along the coasts of Uruguay and southeastern Brazil where they receive many streams and rivers and the dos Patos opens to the Atlantic Ocean. The freshwater catfishes of the area include species of the families Callichthyidae, Heptapteridae, Loricariidae, Trichomycteridae and Pimelodidae (Malabarba, 1989, Garcia and Vieira, 2001). The species described herein adds an endemic species to the regional fauna.

\section{MATERIALS AND METHODS}

Seventeen specimens of the new species were obtained from museum collections and collaborative fieldwork 


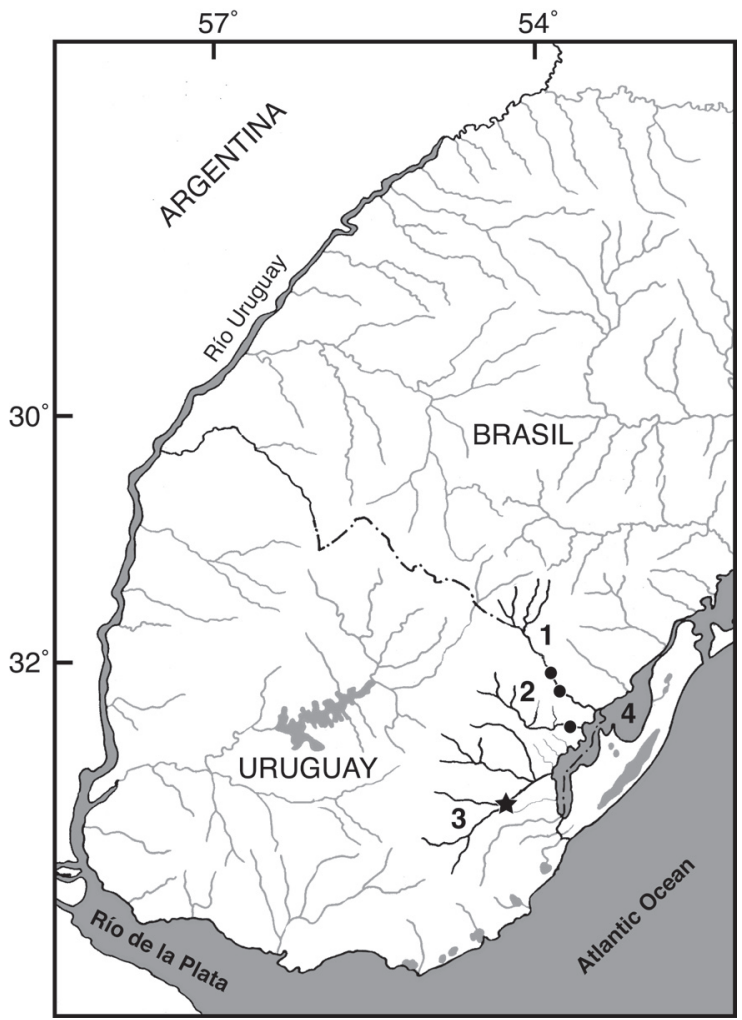

Fig. 1. Geograpahical distribution of Pimelodus pintado n. sp., star indicates the type locality. 1, río Yaguaron, 2, río Tacuarí, 3, río Cebollatí, 4, Laguna Merín.

carried out in Uruguay beginning in 2001. The majority of specimens in the type series are alcohol preserved; two partial skeletons were prepared by manual removal of soft tissues.

Measurements are straight-line distances taken with caliper to nearest $0.1 \mathrm{~mm}$. Measurements follow Azpelicueta (2001) as defined in Lundberg et al. (1991). Proportions are expressed as percentages of standard length (SL), head length (HL), or otherwise as indicated. Counts were made of total fin rays in all fins; vertebral counts include all five elements of the Weberian complex; the compound preural+ural centra is counted as one.

Institutional acronyms are as listed on the Catalog of Fishes website at http://www.calacademy.org/research/ ichthyology/catalog/abtabr.html.

\section{Pimelodus pintado, new species} Figs. 2, 3

Holotype.-ZVC P 6482, 241 mm SL, Uruguay, Departamento Rocha, Merín-Patos System, río Cebollatí in Paso de Averías, close to bridge of Ruta 14, 3336'49” S, 5419'50” W, Feb. 24 2007, coll. M. Azpelicueta, M. Loureiro, S. Clavijo (Fig. 1).

Paratypes.-All from Uruguay. AI 225, 188.6 $\mathrm{mm}$ SL, from the type locality, Feb. 25, 2007. AI 224, 188.0 mm SL, Departamento Cerro Largo, MerínPatos system, río Yaguarón in río Branco, 32³5'S, $53^{\circ} 21^{\prime} \mathrm{W}$, Oct. 30, 2006, coll. P. Laurino, J. Litz, M. Litz, T. Litz, J. Salvia. MNHN 3217, 157 mm SL, collecting data as AI 224. ANSP 187381, 3 specimens including one dry skeleton, 172.0-238.8 mm SL, from the type locality, Feb. 25, 2007. ZVC-P 6483, 5 specimens, 191.0-280.5 mm SL, from the type locality, Feb. 25, 2007. ZVC-P 6484, 149.0 mm SL, Departamento Treinta y Tres, río Tacuarí in Paso del Dragón (Ruta 18), 32 46'18' S, 5344'57' W, Feb. 23, 2001, coll. M. Loureiro. NRM 48001, 4 specimens, 108.3-176 mm SL, Departamento Cerro Largo, Merín-Patos system, río Yaguarón in Paso del Centurión, $32^{\circ} 06^{\prime}$ S, $53^{\circ} 45^{\prime} \mathrm{W}$, No Date, coll. F. Cantera. ANSP 54060, 239 mm SL, Departamento Cerro Largo, 1932, coll. F. Felippone.

Non-type specimen.-AI 235, 1 dry skeleton, Uruguay, río Cebollatí in Paso de Averías.

Diagnosis.-A species of Pimelodus distinguished from congeners by the following combination of features. Larger specimens (>200 mm SL, Figs. 2, 3A) with numerous, irregularly scattered black spots on dorsum and sides of body and head, usually also on dorsal, adipose and caudal fins, and often pectoral, pelvic and anal fins; smaller specimens have larger spots arranged about in 4 rows (Fig. 3B); fresh background color golden yellow (Fig. 3A); lips thick, plicate with prominent rictal folds (Fig. 2C); upper jaw and snout projecting beyond mandibular symphysis, exposing premaxillary teeth; anterior nares relatively remote from snout margin; prevomer toothless; 22-26 gill rakers on first branchial arch.

Description. - Morphometric data for the holotype and 14 paratypes are presented in Table 1. Pimelodus pintado n. sp. (Figs. 2, 3) is a medium sized pimelodid with a maximum known length of 280.5 mm SL. Dorsal profile of body nearly straight from snout tip to base of supraoccipital posterior process, then slightly to strongly convex to dorsal-fin origin, straight or slightly convex from dorsal-fin origin to adipose-fin origin (larger specimens) or end (smaller specimens), straight or slightly concave across caudal peduncle. Ventral profile slanting convexly ventrally 

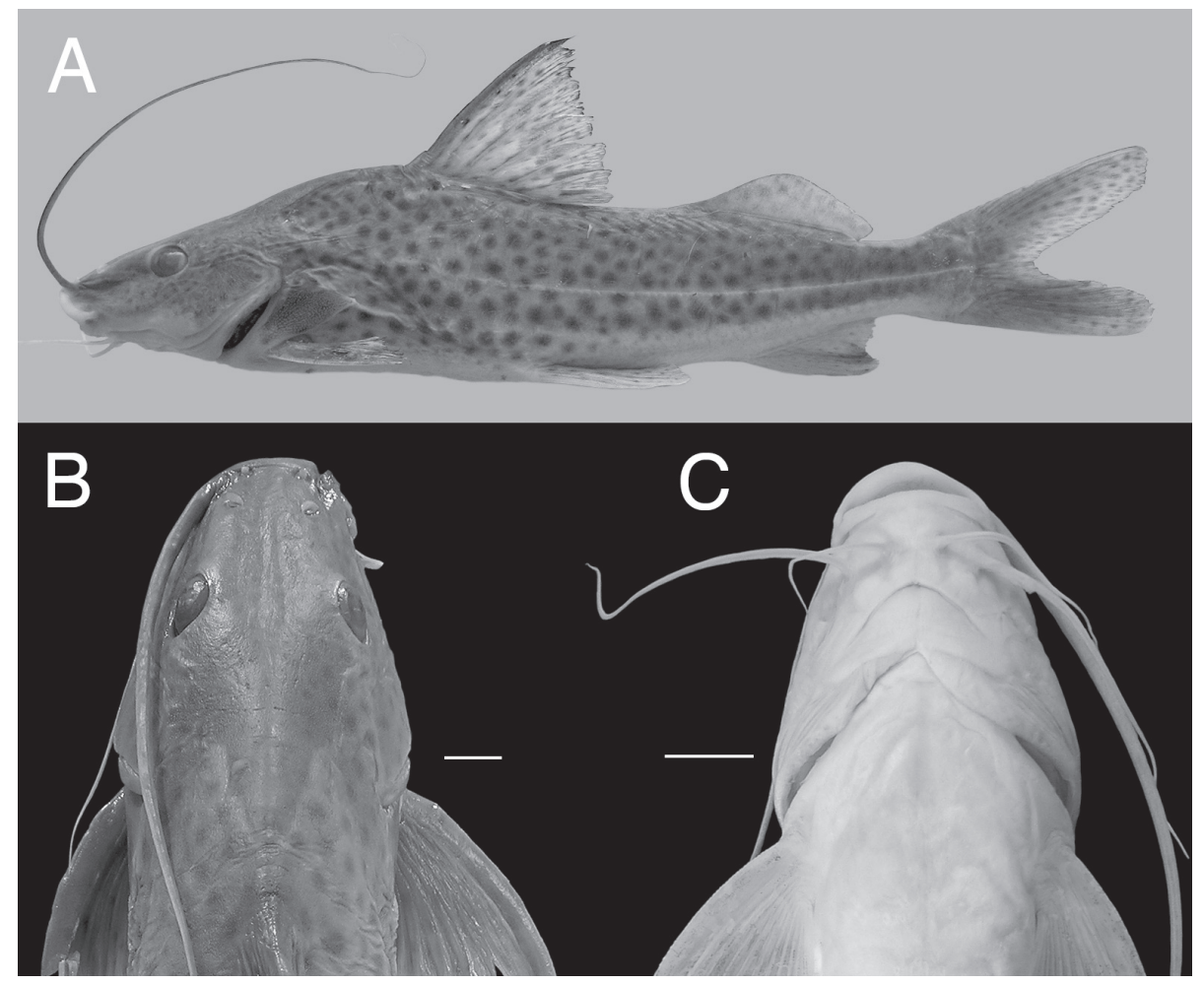

Fig. 2. Pimelodus pintado n. sp. A. Holotype in lateral view, ZVC P 6482, $241 \mathrm{~mm}$ SL, B. Paratype, dorsal view of head, ANSP 54060, $239 \mathrm{~mm}$ SL, C. Paratype, ventral view of head, NRM 48001, $176 \mathrm{~mm}$ SL.

from snout tip to pectoral-fin origin, generally straight or convex across abdomen to anal-fin origin, then slanting dorsally to slightly concave caudal peduncle.

Cross-sectional shape roughly trapezoidal from snout to base of supraoccipital posterior process, then deeply and broadly triangular to dorsal-fin origin, and increasingly compressed to caudal fin. Maximum body depth at dorsalfin origin, contained 3.8-4.9 times in SL. Maximum body width across cleithra in front of pectoral spine insertions, contained 4.5-5.6 times in SL.

Head of moderate length, contained 3.3-3.6 times in SL, and relatively deep (head depth at base of supraoccipital posterior process equal to body width. Head covered by thin skin and a thick layer of mucus, posterior half of skull roof weakly ornamented with small closely packed tubercles. Snout long, more so in larger fish, contained 2-2.9 in head length, rounded profile in dorsal view. Upper jaw projecting and relatively longer in larger specimens; with mouth closed premaxillary teeth broadly exposed except in largest specimens with much thickened lips. Anterior nostril with a short tubular rim and relatively far from lips; distance between anterior nostril and snout margin about
$80 \%$ of distance between both naris (Fig. 2A). Distance between anterior and posterior nostrils less than distance between the latter and anterior orbital margin. Long axis of the posterior nostril oblique to longitudinal body axis; posterior nostril preceded by a large, semicircular membrane.

Eye large, placed dorsolaterally and centered a little behind midpoint of bony head length; interorbital space scarcely concave or flat. Depth of head between eyes 1.82.2 times into HL; width of head at eye 1.3-1.8 times into HL. Interorbital wide, containing horizontal eye diameter 1.0-1.6 times. Anterior fontanelle narrowly triangular, originating half way between posterior nostrils and anterior margin of orbit, its broad posterior end located at about level of posterior margin of orbit. Posterior fontanelle present only in smallest specimens as an oval aperture and closing completely with growth. Supraoccipital posterior process strong, broad-based (its basal width 1.2-1.4 times in length), reaching broad anterior nuchal plate; dorsally abruptly but smoothly rounded, not angular or keeled.

Mouth subterminal, opening anteriorly and widely; gape width across inner surface of ricti a little greater than 
Table 1. Measurement data for Pimelodus pintado expressed (except for whole-fish standard length, mm) in percentages of the standard dimensions given above measurements.

\section{Standard Length}

Percent of SL

Predorsal length

Preadipose length

Prepectoral length

Prepelvic length

Preanal length

Body depth at dorsal-fin origin

Body depth at adipose-fin origin

Caudal peduncle depth

Caudal peduncle length

Head length

Body width

Dorsal spine length, bony

Longest (1st) dorsal-fin ray

Dorsal-fin base

Last dorsal-fin ray to adipose-fin origin

Adipose-fin length

Adipose-fin height

Pectoral-spine length, bony

Longest (2nd) pectoral-fin ray

Longest (2nd) pelvic-fin ray

Anal-fin base

Anal-fin height

Dorsal-fin origin to caudal-fin base

Pelvic-fin origin to caudal-fin base

Anal-fin origin to caudal-fin base

Pectoral-fin to pelvic-fin origin

Pelvic-fin to anal-fin origins

\section{Percent of head length}

Snout length

Horizontal eye diameter

Eye to posterior margin of head

Bony interorbital

Head depth at eyes

Head depth at occiput

\begin{tabular}{|c|c|c|c|c|}
\hline Holotype & Mean & Min & Max & SD \\
\hline 241 & & 108.2 & 280.5 & \\
\hline 59.3 & 40.3 & 39.3 & 41.2 & 0.55 \\
\hline 61.7 & 66.3 & 61.8 & 69.0 & 1.68 \\
\hline 26.1 & 26.4 & 24.4 & 28.4 & 1.2 \\
\hline 50.1 & 51.0 & 49.0 & 54.7 & 1.81 \\
\hline 74.6 & 73.0 & 70.6 & 75.5 & 1.45 \\
\hline 21.7 & 23.2 & 20.4 & 27.0 & 1.75 \\
\hline 17.0 & 17.9 & 15.1 & 20.9 & 1.74 \\
\hline 7.9 & 8.1 & 6.6 & 9.1 & 0.61 \\
\hline 18.2 & 17.7 & 14.9 & 19.2 & 1.06 \\
\hline 28.0 & 28.9 & 27.9 & 30.1 & 0.65 \\
\hline 18.2 & 19.1 & 17.9 & 22.0 & 0.92 \\
\hline 20.1 & 21.8 & 20.1 & 23.1 & 0.97 \\
\hline 22.3 & 23.9 & 22.2 & 26.0 & 1.05 \\
\hline 14.9 & 15.5 & 14.5 & 17.0 & 0.59 \\
\hline 14.0 & 13.0 & 11.1 & 15.7 & 1.41 \\
\hline 21.2 & 21.7 & 19.0 & 25.4 & 1.51 \\
\hline 5.3 & 5.2 & 4.2 & 6.2 & 0.53 \\
\hline 18.8 & 20.3 & 17.3 & 23.0 & 1.61 \\
\hline 19.4 & 22.1 & 19.4 & 23.6 & 1.01 \\
\hline 17.8 & 18.9 & 16.5 & 24.2 & 2.26 \\
\hline 12.1 & 11.9 & 10.4 & 13.5 & 0.93 \\
\hline 15.1 & 16.5 & 15.1 & 18.2 & 0.97 \\
\hline 63.5 & 63.6 & 60.8 & 66.1 & 1.4 \\
\hline 51.3 & 51.3 & 49.4 & 54.0 & 1.34 \\
\hline 28.8 & 29.5 & 27.6 & 32.2 & 1.25 \\
\hline 25.2 & 26.0 & 23.1 & 30.1 & 1.9 \\
\hline 23.8 & 23.2 & 21.3 & 24.7 & 1.03 \\
\hline 46.7 & 45.5 & 36.7 & 48.2 & 2.71 \\
\hline 17.5 & 19.2 & 16.3 & 22.7 & 2.17 \\
\hline 37.3 & 37.7 & 33.8 & 41.7 & 1.92 \\
\hline 28.5 & 25.2 & 22.1 & 29.0 & 1.94 \\
\hline 48.6 & 49.1 & 44.1 & 52.7 & 3.33 \\
\hline 65.8 & 64.5 & 60.3 & 70.6 & 2.62 \\
\hline
\end{tabular}


Table 1. cont

Head width

Gape width

Premaxillary width

Snout to anterior nostril

Distance between nares

Posterior naris/anterior eye margin

Projection of upper jaw

\begin{tabular}{ccccc} 
Holotype & Mean & Min & Max & SD \\
\hline 66.4 & 66.8 & 61.1 & 70.0 & 2.21 \\
35.1 & 33.2 & 30.3 & 36.3 & 1.83 \\
21.7 & 21.2 & 19.2 & 21.9 & 0.77 \\
9.8 & 11.0 & 9.2 & 12.8 & 0.94 \\
10.8 & 13.3 & 10.8 & 16.6 & 1.58 \\
22.3 & 22.5 & 19.1 & 26.8 & 2.15 \\
13.7 & 10.9 & 8.1 & 14.1 & 2.02
\end{tabular}

\section{Percent of peduncle length}

Caudal peduncle depth

46.1

37.4

54.0

4.74

\section{Percent of bony interorbital}

Eye

74.9

$62.3 \quad 96.4$

11.94

\section{Percent of gape mouth}

Premaxillary width

68.2

62.9

58.1

68.2
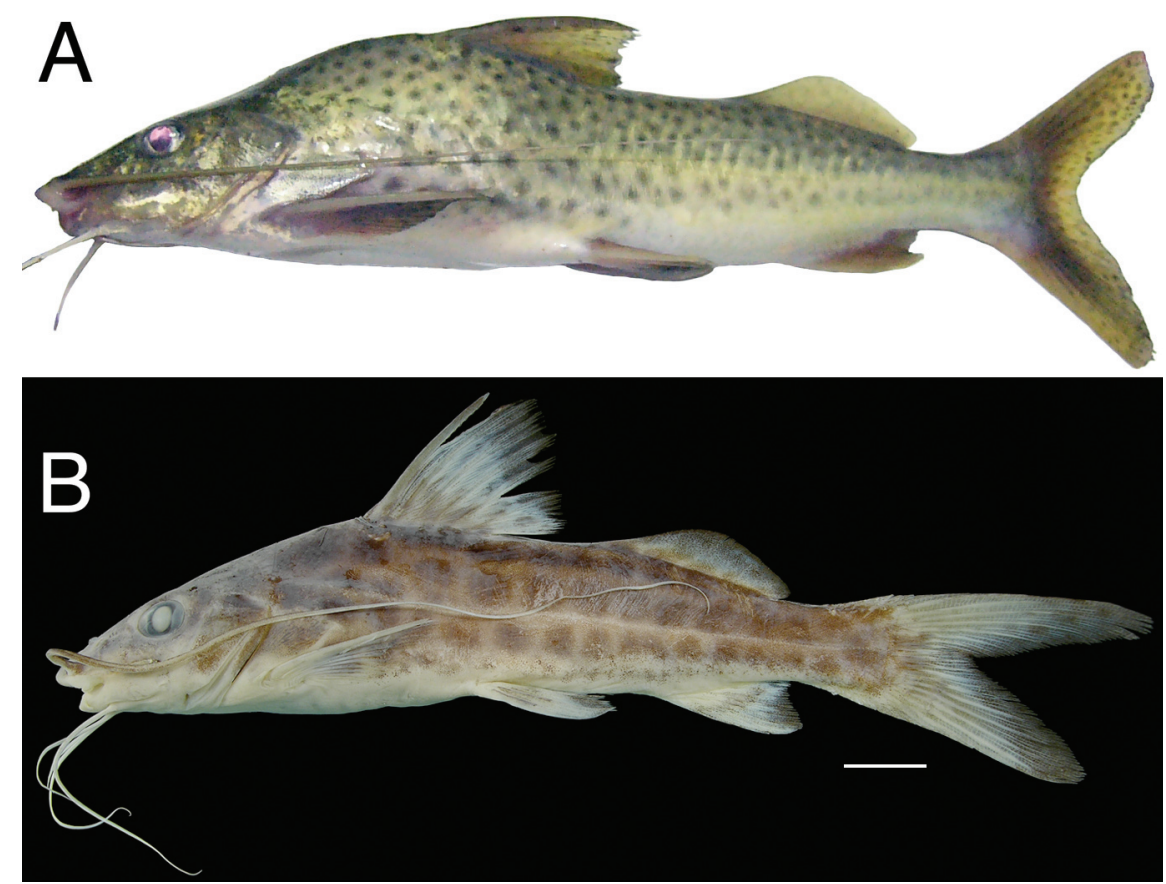

Fig. 3. Pimelodus pintado n. sp. A. Fresh holotype, ZVC P 6482, photograph by M. Loureiro (note: dorsal fin is tilted laterally off the sagittal plane and thus appears foreshortened). B. Paratype showing juvenile pigmentation pattern, NRM 48001, $108.3 \mathrm{~mm} \mathrm{SL}$. 
interorbital width. Lips thick, fleshy and noticeably plicate, increasingly so in large specimens. Rictal folds fleshy and prominent, subtended above and below by deep folds respectively reaching base of maxillary barbel and nearly half the distance to mandibular symphysis. Premaxillary tooth bands of uniform length along their transverse width (overall width of both bands 1.2-1.7 times in mouth width), anterior margin more strongly curved than snout margin and with bluntly rounded posterolateral corners. Premaxillary teeth conical and fine, placed in 8-14 irregular rows, more numerous in larger specimens. Dentary teeth similarly slender and, in largest specimens, arranged in about 10 rows at symphysis and fewer posteriorly. No prevomerine or palatal teeth.

Origin of maxillary barbel in a depression close to base of anterior nostril and above rictus; maxillary barbel in young specimens reaching to a vertical through procurrent caudal-fin rays, and shorter in larger fish reaching pelvic fin. Outer mental barbel reaching last third of pectoral fin in adults. Tip of inner mental barbel scarcely reaching pectoral-fin origin, usually half way between margin of branchiostegal membrane and pectoral-fin origin. Branchiostegal membranes anteriorly united to isthmus, diverging at once without overlap. Eight branchiostegal rays. Gill rakers (in 12 specimens) long, conical, 22 to 26 on first gill arch: 5-7 rakers on upper limb, 1 at cartilaginous angle, and 16 to 18 on lower limb; holotype: $7+1+16$.

Dorsal-fin lepidotrichia II, 6; the first a short, broad spinelet; dorsal-spine long and strong, its shaft longitudinally striate, its anterior margin smooth, its posterior margin weakly serrate along distal third. First dorsal-fin soft ray the longest, neither it nor dorsal spine filamentous. Dorsal-fin origin at vertical through posterior third of pectoral fin; distal margin almost straight. Adpressed dorsal-fin tip falls before adipose-fin origin, increasingly so in larger specimens. Adipose-fin origin located at a vertical through tip of pelvic fins and remote from posterior insertion of dorsal-fin. Adipose fin of moderate length, shorter than head and contained 4.0-5.2 times in SL, and low, its height contained 3.4-5.0 times in its base.

Caudal fin deeply forked, its lower lobe shorter, more rounded and scarcely broader than upper lobe; inner margins of both lobes convex. Principal caudal-fin rays 1,7-8,1. Anal-fin origin at a vertical through first third of adipose fin, and its posterior insertion before end of adipose fin, distal margin of anal fin slightly concave, first three branched rays forming a short lobe at least in smaller specimens. Anal-fin rays v-vi, 7-10 (1 with 7 branched rays; 4 with $8 ; 7$ with $9 ; 3$ including holotype with 10 ).

Pectoral fin I, 8-11 (1 with 8 branched rays; 4 including holotype with $9 ; 6$ with $10 ; 4$ with 11$)$. Pectoral spine strong; its anterior margin with small dentations along proximal two thirds in young specimens, becoming obsolete in adults. Pectoral-spine posterior margin with well developed, retrorse and regularly spaced dentations on distal two thirds; largest specimens with smaller serrae along entire spine. Dorsal and ventral pectoral-spine surfaces striate, less so on ventral surface. Pectoral-fin first branched ray almost equal to spine and its soft-raylike tip. A pectoral axillary gland pore, close to ventral margin of posterior cleithral process. Posterior cleithral process deep, broad, sharply pointed, covered with finely tuberculate sculpture; ventral margin of process almost in contact with base of pectoral fin. Pelvic fin with i,5 rays; second branched ray longest; its outer corner rounded and distal margin straight. Pelvic-fin insertion approximately in line with posterior insertion of dorsal fin. Tip of pelvic fin surpassing midpoint between origins of pelvic fins and anal fin; nearer anal-fin origin in small specimens. Inner pelvic-fin ray surpassing anus and urogenital papillae.

Urogenital papilla located immediately behind anus, triangular with broad base in males. Gonads of males with numerous finger-like projections.

Lateral line complete, straight and terminating on the caudal fin; a few anterior lateral line ossicles with small plate-like expansions.

Swim bladder heart-shaped, without projections, internally divided into three incompletely separated chambers; sonic muscle fibers covering only anterior surface of swim bladder.

Total number of vertebrae, including the five elements in the Weberian complex, 41-42 $(n=5) ; 17-18$ precaudal and 24-25 caudal. In two specimens eleven pairs of ribs.

Coloration.-Color upon capture (Fig. 3A). Background dark to light golden yellow with a metallic sheen; lower half of flanks and venter whitish. Many black dots irregularly distributed on flanks, head and all fins. Dots on head, cheeks and fins smaller than those on body. Dots more numerous on anterior half or two thirds of body; in some specimens, dots forming about 5 to 9 irregular rows independently of body size.

Color in alcohol (Fig. 2). Grayish, darker on upper half of flanks and head, lower part of flanks and venter cream-whitish. A narrow, whitish longitudinal stripe over lateral line sensory canal. Younger specimens with another light line between rows of spots about midway between lateral line and mid-dorsal line. Black dots irregularly placed although sometimes arranged as five to nine irregular rows on posterior half of body; dots more abundant on anterior part of body. Younger specimens (Fig. 3B) with relatively larger spots arranged about in 4 rows. Dorsal surface of head and cheeks with numerous small dots; all fins faintly spotted. Many speciemens with a light band 


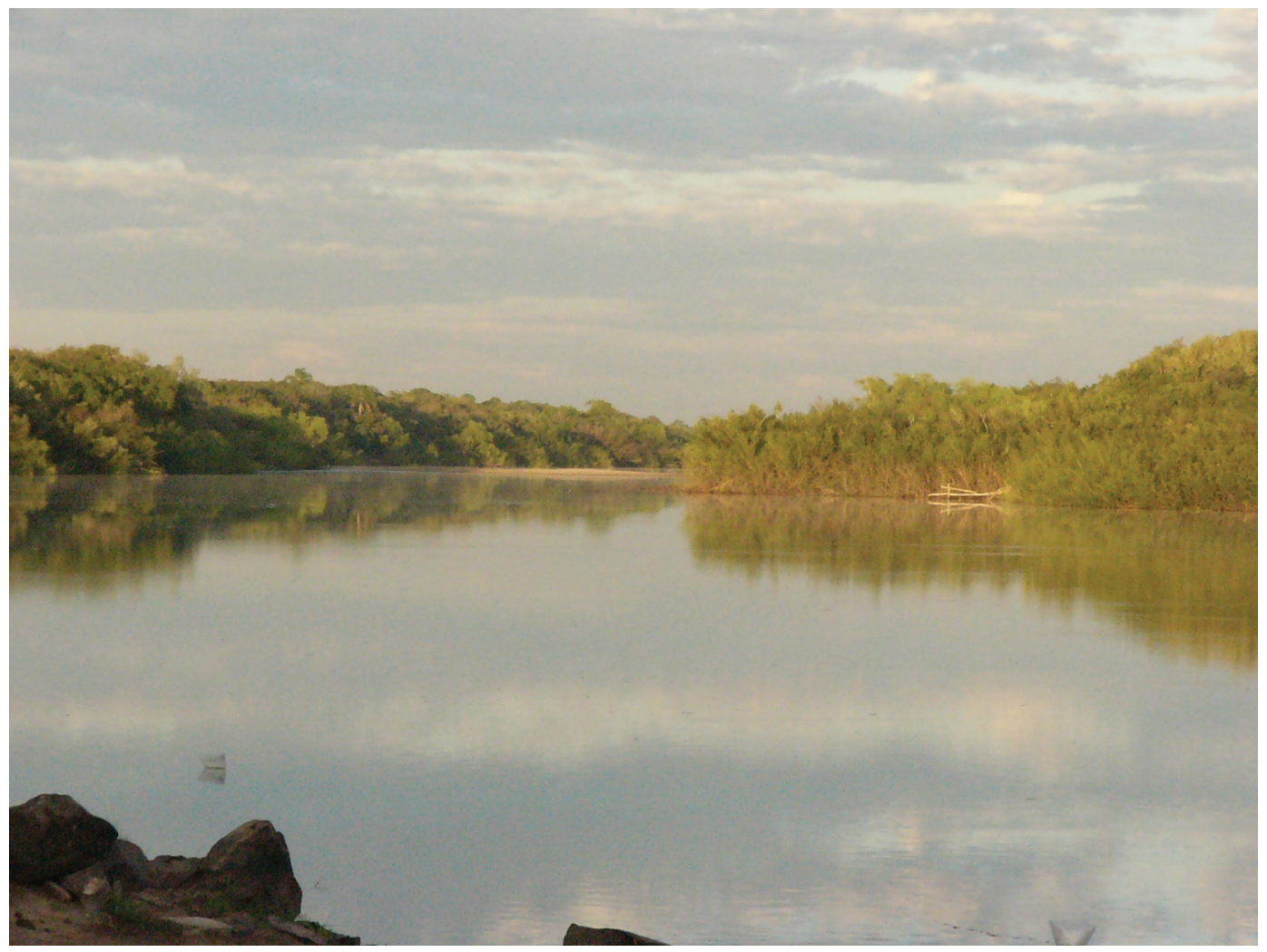

Fig. 4. Type locality of $P$. pintado along the río Cebollatí, Uruguay.

close to base of dorsal fin. Margin of caudal fin in some specimens black; distal margin of adipose and anal fins dark gray. Dorsal surface of paired fins dark gray. A light area around interopercle.

Etymology. - The Spanish word pintado means spotted or with points. People living in the area of Paso de Averías, on the Cebollatí River, use the name pintado as the common name for the species. Hence, we apply this name as a noun in apposition.

Distribution and Biology.-Pimelodus pintado is known from three affluent rivers of Laguna Merín Uruguay (Fig. 1). Twelve specimens, including the designated holotype, were collected in the río Cebollatí where the river has sandy bottom and slow current at the time of the capture (Fig. 4). Specimens were captured with baited hooks and beach nets, in 0.8-1 $\mathrm{m}$ depth; specimens were not captured in the deeper main channel of the river. Stomachs and complete intestines of two specimens were full with minute empty gastropod shells.

\section{DISCUSSION}

Among the species of Pimelodus distributed south of the Amazon Basin P. heraldoi, $P$. absconditus, $P$. microstoma, $P$. paranaensis, $P$. platicirris, $P$. ortmanni, $P$. britskii and $P$. fur, are similar to $P$. pintado in sharing some

Fig. 5. (pages 156-158) Diversity of spotted pigmentation patterns illustrated by type and other specimens of nine species of Pimelodus. Scale bar $=1 \mathrm{~cm}$. A, P. heraldoi, MZUSP 22712, Paratype; B, P. absconditus, ANSP 182421; C, P. paranaensis, MZUSP 23089, Holotype; D, P. paranaensis, MZUSP 24454, Paratype; E, P. platicirris, AMNH 8626, Holotype; F, P. platicirris, AI 228; G, P. ortmanni, FMNH 54240, Holotype; H, P. britskii, FMNH 105098, Holotype; I, P. fur, MZUSP 73740; J, P. maculatus, ANSP 182442, juvenile; K, P. maculatus, ANSP 181019, adult; L, P. mysteriosus, ANSP 187392; M, P. sp. from Peruvian Amazon, ANSP 179457, photograph by M. Sabaj; N, P. punctatus, FMNH 7577, Holotype; O, P. grosskopfi, ANSP 147077; P, P. navarroi, USNM 121174, Holotype; Q, P. coprophagus, USNM 121150, Holotype showing "profusely spotted" pigmentation phase (Schultz, 1944); R, P. coprophagus, MZUSP uncat., showing streaked and blotched pigmentation phase (Schultz, 1944). 


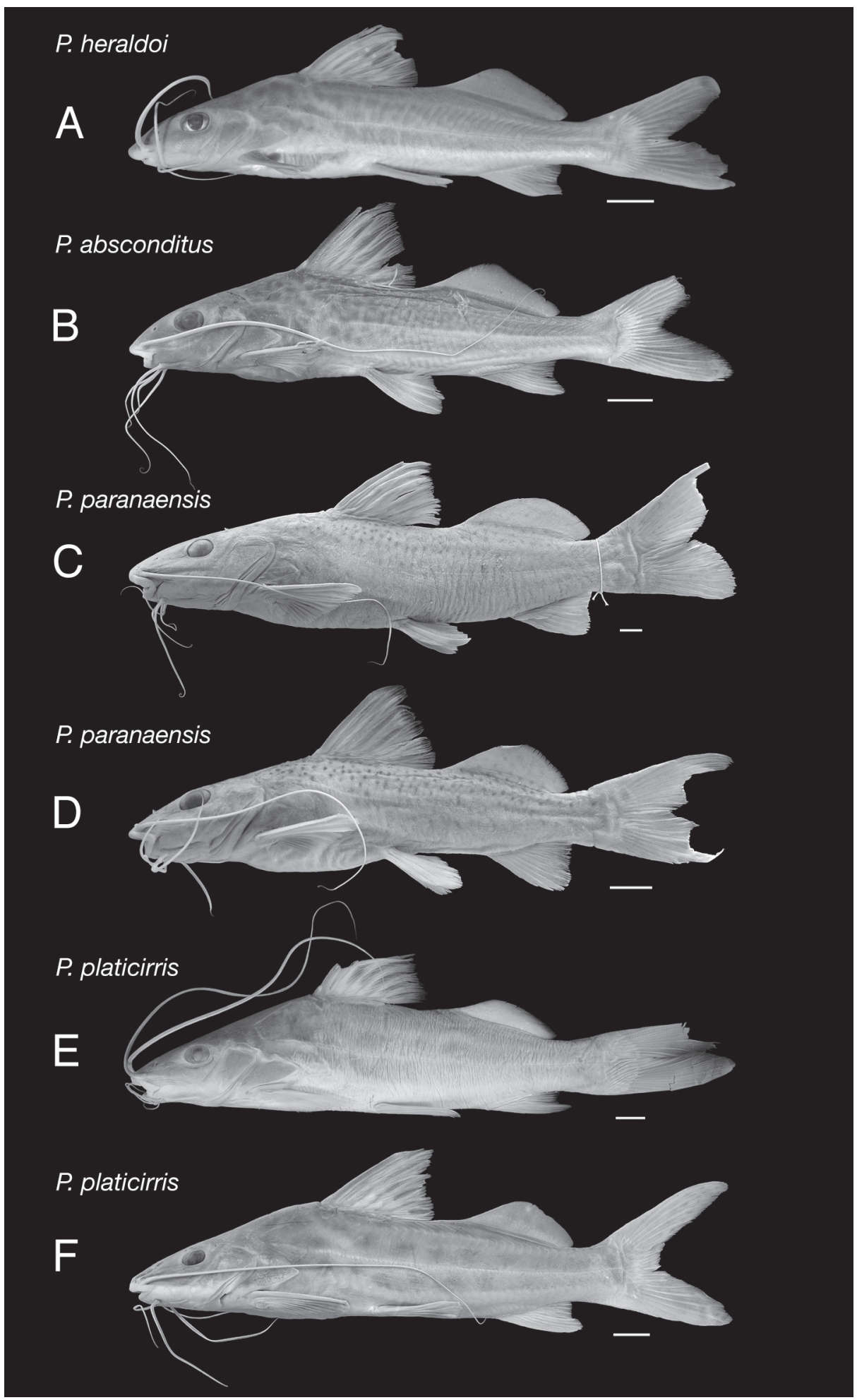




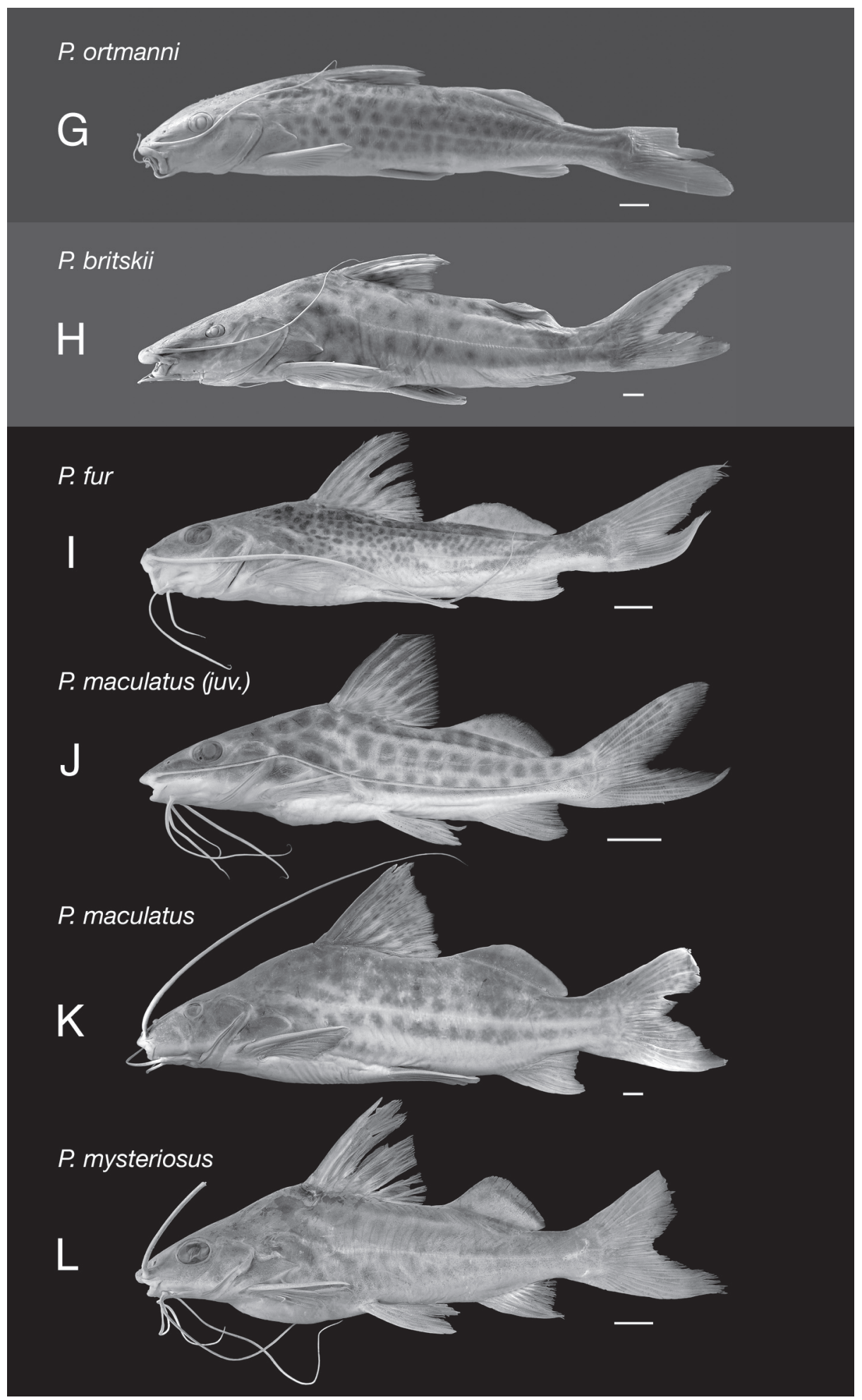



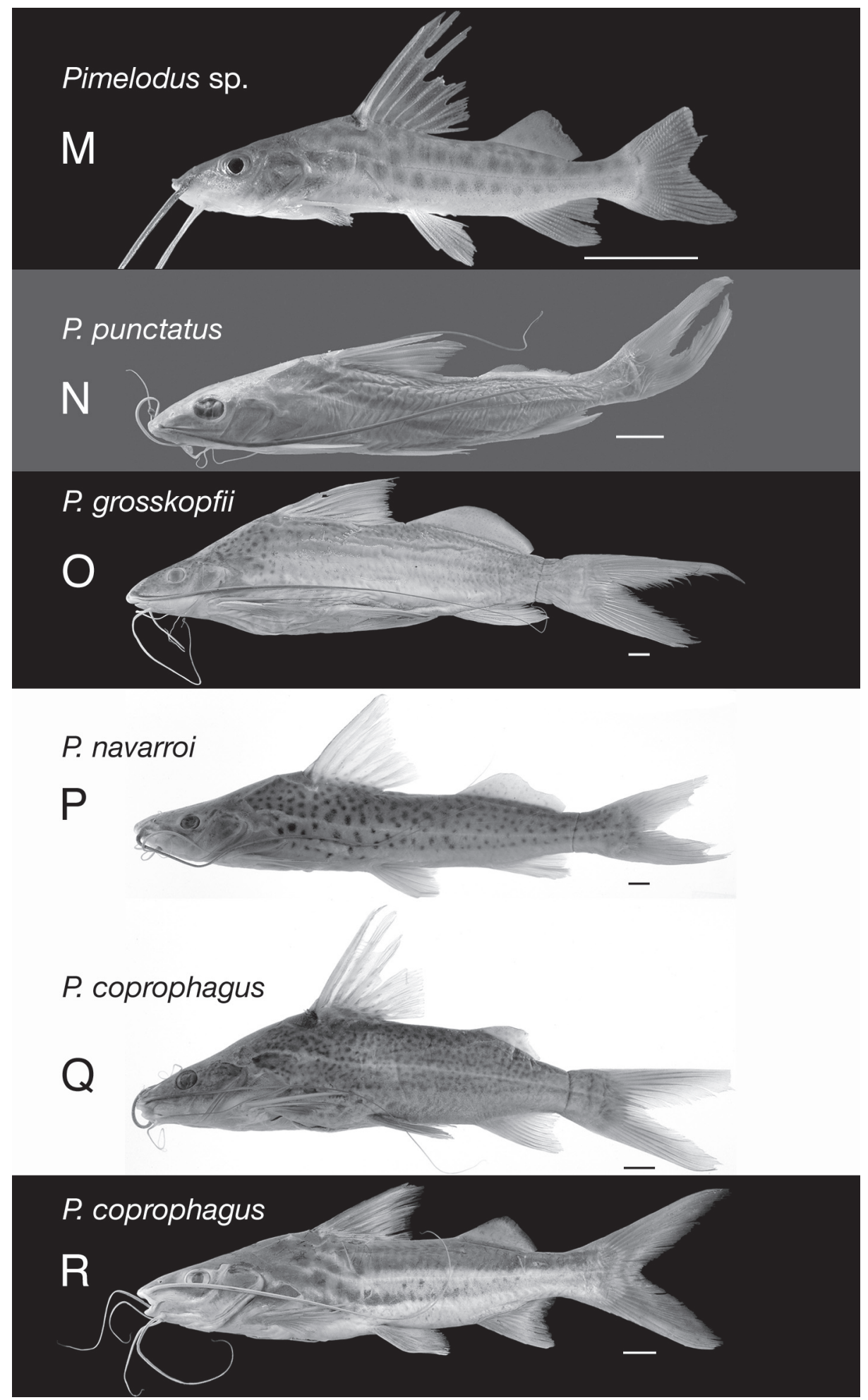
degree of spotting (cf. Figs. 2, 3, 5), as well as projecting upper jaws and thickened, plicate lips. Pimelodus heraldo $i$ (Fig. 5A) is most similar to P. pintado overall but differs in having a darker gray-brownish background with fainter spots on the sides posteriorly, and variable or no spots on the fins. Also, $P$. heraldoi has fewer gill-rakers (19-22 vs. 22-26 in $P$. pintado), a longer adipose-fin base (25.7$28 \%$ vs. $19-26 \%$ of SL; Fig. 6), and the variable presence of prevomerine teeth (absent in $P$. pintado). Further, $P$. heraldoi has a shorter predorsal distance (36.2-39.9\% vs. $39.3-41.7 \%$ of SL), relatively longer dorsal-fin base (15.8$17.8 \%$ vs. $14.5-16.9 \%$ of SL), longer snout (45.7-51 vs. $36.7-48.2 \%$ of HL), greater distance between pelvic and anal fins (23-26.4\% vs. $21.3-24.7 \%$ of SL), shorter head (25.8-28.9 vs. $27.9-30$ of SL), and wider interorbital distance (22.2-29.1 vs. 21.3-24.7\% of HL).

Pimelodus absconditus (Fig. 5B) is readily distinguished from $P$. pintado by having a less extensively spotted pigmentation pattern and gray-greenish background color, fewer gill-rakers (19-21), presence of prevomerine teeth, and relatively narrower interorbital width (18.6-22.7 vs. 22-29\% of HL). Pimelodus microstoma is similarly more uniformly pigmented than $P$. pintado with few anterior spots, and fewer gill rakers (17-22).

Pimelodus paranaensis (Fig. 5C, D) has small dots scattered above the lateral line on the trunk but not on the fins or head, and the premaxilla has pointed posterolateral corners (vs. rounded in other maculated species of Pimelodus). Pimelodus platicirris (Fig. 5E, F) has 3 to 5

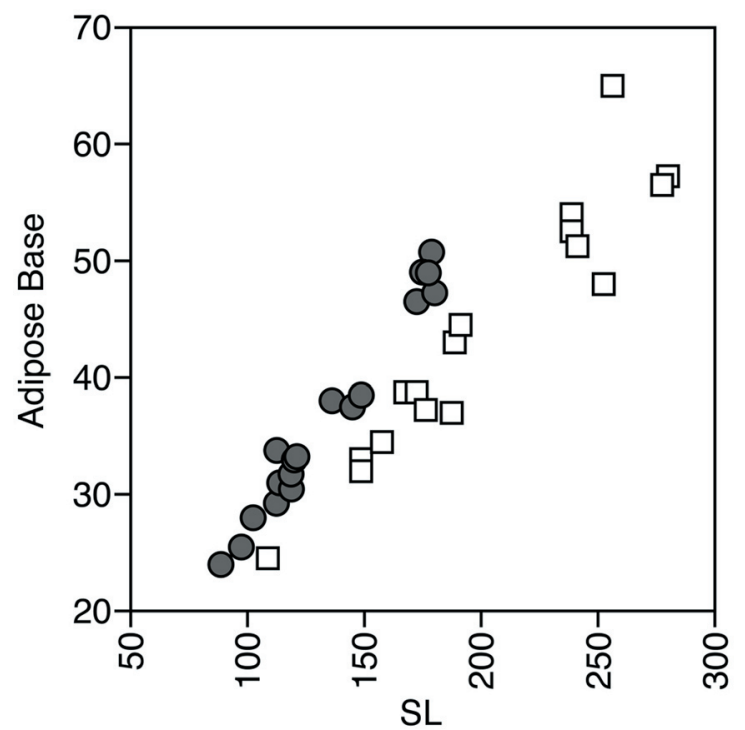

Fig. 6. (above) Scatter plot illustrating shorter adipose-fin base relative to standard length in $P$. pintado (squares) compared to $P$. heraldoi (circles), graph by K. Luckenbill. irregular rows of dots along the sides, 20-23 gill rakers (in the holotype and 5 specimens from the type locality), and a shallower head (head depth 50.5-64.4\% of HL; vs. 60.3$70.6 \%$ in $P$. pintado).

Pimelodus ortmanni (Fig. 5G) differs sharply from $P$. pintado in its more bluntly rounded and conical snout, distinctly ventral mouth with a more circular gape surrounded by thicker lips. Smaller specimens of P. ortmanni are extensively spotted on the sides and dorsal fin, but with growth spotting becomes limited to the anterodorsal flanks and reduced to 6-10 rows. Pimelodus ortmanni is notably different from other observed species of the genus in having large fleshy lobes or pads on the branchial arches. Pimelodus britskii (Fig. 5H) was recently described by Garavello and Shibbata (2007) from the rio Iguaçu where it is syntopic with P. ortmanni. Like the preceding species of the Parana Basin, P. britskii is spotted and has thickened lips, but post-juveniles of this species are less densely and boldly spotted than $P$. pintado.

Pimelodus fur (Fig. 5I) from the São Francisco River has a much lower gill raker count (15-18) than P. pintado, and also has a distinctively narrower mouth (24.6-30 vs. $30.3-36.3 \%$ of HL) and much fainter spotting pattern. Pimelodus maculatus like P. pintado, shows a bright yellow to golden background color in life, but at all sizes (Fig. $\mathrm{J}, \mathrm{K}$ ) differs trenchantly from the new species in having many fewer and larger spots arranged in few (3-5) rows and lacks (except in small specimens) dots on the top of the head, and dorsal and paired fins. However, P. maculatus, differs markedly from $P$. pintado and the foregoing species in having scarcely thickened lips and rictal folds, with a smooth or weakly plicate texture, and the snout is less projecting at all sizes with the anterior nares closer to the snout margin and the premaxillary tooth band is broader. Pimelodus mysteriosus (Fig. 5L) is also yellow or silvery yellow when fresh, but this is a small species (SL $<200$ $\mathrm{mm}$ ), with 3-4 rows of regularly arranged spots, large eye (25.1-31.6 vs.16.3-22.7\% of HL) and teeth on metapterygoid.

None of the described species of Pimelodus from the Amazon, Orinoco or Guianas have such an extensive, irregular or otherwise similar spotting pattern as $P$. pintado. However, an apparently undescribed species (Fig. 5M) from the Peruvian Amazon that is possibly close to P. blochii has three to four rows of larger spots similar to those of P. maculatus. Four species of the genus from transAndean South America are extensively and often densely spotted: P. punctatus (río Tuyra, Panama), P. grosskopfii (Magdalena-Cauca sytem), and from the Lake Maracaibo basin $P$. navarroi and $P$. coprophagus. The spots on the sides of P. punctatus (Fig. 5N) and P. grosskopfii (Fig. 5O) are smaller and sparser than those of $P$. pintado and are 
absent from the fins. Further, the maxillary barbels of $P$. grosskopfii and $P$. punctatus are long, reaching onto the caudal fin vs. onto the pelvic fins in $P$. pintado.

Pimelodus navarroi (Fig. 5P) was described as a subspecies of $P$. grosskopfii occurring in the Lake Maracaibo Basin (Schultz, 1944) but is now recognized as a distinct species (Lundberg and Littmann, 2003). Although the spots on the body of $P$. navarroi and $P$. pintado are similar in size and are present on the dorsal fins, the fin-spotting is less dense in $P$. navarroi and lacking on the other fins. Also, $P$. navarroi has longer maxillary barbels reaching onto the anal-fin in adults (vs. to the pelvic fins in $P$. pintado); a shorter adipose-fin contained (22.2-22.5 vs. $27.2-32.2 \%$ of SL) and a shorter head (24.8-25.8 vs. $27.9-30.1 \%$ of SL).

Schultz (1944) described $P$. coprophagus as a subspecies of so-called $P$. clarias from the río Magdalena, Colombia, but these are distinct species (Lundberg and Littmann, 2003). The holotype of P. coprophagus (Fig. 5Q) exhibits a "profusely spotted" pigmentation phase combining irregular vermiculations and dots, plus a prominent light stripe over the lateral line. This pattern differs starkly from $P$. pintado. Schultz (1944) suggested that $P$. coprophagus has considerable color pattern variation with many specimens exhibiting a streaked and blotched pigmentation phase (Fig. 5R). The taxonomic significance of pigmentation and morphometric variation of $P$. coprophagus needs reexamination but that is beyond the scope of this study.

\section{COMPARATIVE MATERIAL EXAMINED}

Unless otherwise indicated specimens are alcohol preserved. Abbreviations: C\&S - cleared/stained; SK - dry skeleton; XR - radiograph (in addition to alcohol preserved); $\mathrm{PH}$ - published photograph or illustration with reference; ACSI + original binomen - on-line image in All Catfish Species Inventory Image Base (http://acsi. acnatsci.org/base/, Morris and Sabaj, 2006); CAS + original binomen - on-line image in Primary Types Image Base (http://www.calacademy.org/research/ichthyology/Types/, California Academy of Sciences, 2007).

Pimelodus absconditus: MLP 8781, Holotype, specimen and PH (Azpelicueta, 1995, Figs. 1-2), Argentina, r. Uruguay; MLP 8784, Paratype, 1 C\&S, Argentina, r. Uruguay; MLP 9115, Paratype 1, Argentina, r. Corrientes; CAS 82324, Paratype 1, Argentina, r. Uruguay; FMNH 104890, Paratypes 2, Argentina, r. Uruguay; MZUSP 44742, Paratypes 2, Argentina, r. Uruguay; ANSP 182421, 1, Argentina, r. Paraná; ANSP 187382, 2, Argentina, r. Uruguay. Pimelodus albicans: MNHN A-9400, Holotype, ACSI as Arius albicans, Argentina; ANSP 187383, 1, Argentina, r. Corrientes; MLP 8991, 2 C\&S, Argentina;
ANSP 178802, 1 SK, Argentina, r. La Plata. Pimelodus albofasciatus: RMNH 26156 Holotype, Surinam, Sipaliwini, specimen and PH (Mees, 1974, pl. 4); RMNH 26517, Paratypes 2, Surinam, Sipaliwini; ANSP 179717, 1, Guyana, r. Rupununi; ANSP 165237, 1 C\&S, Venezuela, r. Orinoco; ANSP 180626, 1 SK, Guyana, r. Essequibo. Pimelodus altissimus: CAS 55369, Holotype, CAS, XR as Pimelodus altissimus, Peru, r. Ucayali; MZUSP 45516, 1, Brazil, r. Negro; ANSP 179226, 1, Brazil, r. Amazon; ANSP 178519, 1 SK, Brazil, r. Amazon. Pimelodus argenteus: MSNG 14570, Syntypes 2, ACSI as Pimelodus argenteus, Argentina, r. Paraná; ANSP 187384, 2, Argentina, r. Paraná; ANSP 181017, 1 SK, Argentina, r. Paraná. Pimelodus atrobrunneus: MCP 19678, Holotype, specimen and PH (Vidal and Lucena, 1999, Figs. 1-3), Brazil, r. Ligeiro; MLP 8195, Paratype 1, Brazil, r. Uruguay. Pimelodus blochii: MNHN B-0072, Lectotype, ACSI as Pimelodus blochii, Surinam; ANSP 160556, 1, Venezuela, r. Orinoco; ANSP 179191, 1, Brazil, r. Amazon; MZUSP 7603, 1 C\&S, Brazil, r. Amazon; ANSP 187385, 1 SK, Brazil, r. Amazon; ANSP 187386, 1 SK, Brazil, r. Amazon; DU F988, Venezuela, r. Apure; DU F1038, 1 SK, Venezuela, r. Apure; DU F1077, 1 SK, Venezuela, r. Apure; DU F1094, 1, Venezuela, r. Apure; DU F1096, 1 SK, Venezuela, r. Apure; DU F1101, 1 SK, Venezuela, r. Apure; ANSP 178106, 1 SK, Peru, r. Amazon; ANSP 178169, 1 SK, Peru, r. Amazon; ANSP 178263, 1 SK, Peru, r. Amazon; ANSP 179423, 1 SK, Guyana, r. Rupununi. Pimelodus britskii: FMNH 105098, Holotype, PH (Garavello and Shibatta, 2007, Fig. 4) and ACSI as Pimelodus britskii, Brazil, r. Iguaçu. AI 229, 1, Brazil, r. Iguaçu. Pimelodus coprophagus: USNM 121150, Holotype, PH (Schultz, 1944, Fig. 2) and ACSI as Pimelodus clarias coprophagus, Venezuela, r. Agua Caliente; MBUCV uncatalogued, 2 XR, Venezuela, r. Tarra; MBUCV uncatalogued, 4 XR, Venezuela, r. Tarra; MBUCV uncatalogued, 8 SK, Venezuela, r. Tarra. Pimelodus fur: ZMB 91811, Syntype, Brazil, r. das Velhas, ACSI as Pseudorhamdia fur; ZMUC 286, 291, Syntypes 2, Brazil, r. das Velhas; MZUSP 39385, 2, Brazil, r. São Francisco; MZUSP 39748, 4, Brazil, r. São Francisco; ANSP 172141, 4, Brazil, r. São Francisco; MZUSP 39701, 1 C\&S, Brazil, r. São Francisco; MZUSP 85477, 3 SK, Brazil, r. São Francisco. Pimelodus grosskopfii: NMW 45781-82, Syntypes, Colombia, r. Cauca, ACSI as P. grosskopfii; ANSP 147077, 3, Colombia, r. Miel; FMNH 57699, 6, Colombia, r. Magdalena; DU F919, 1 SK, Colombia, r. Magdalena. Pimelodus heraldoi: MZUSP 22713, Holotype, PH (Azpelicueta, 2007, Figs. 1-2), Brazil, r. Mogi Guaçu; MZUSP 22712, Paratypes 29, Brazil, r. Mogi Guaçu; MLP uncat, 1 C\&S, Brazil, r. Paranaiba; MLP 9186, 1 SK, Brazil, r. Mogi Guaçu. Pimelodus jivaro: CAS 55891, Syntypes, 3 CAS as Pimelodus jivaro, Peru, r. Morona; 
ANSP 187387, 4, Brazil, r. Amazon; ANSP 187388, 1, Brazil, r. Amazon; ANSP 187389, 1 CS, Brazil, r. Amazon. Pimelodus maculatus: ANSP 172160, 5, Brazil, r. São Francisco; ANSP 181019, 2 + 3 SK, Argentina, r. Paraná; ANSP 178801, 3 SK, Argentina, r. Paraná; ANSP 180504 2, Argentina, r. La Plata; ANSP 182442, 1, Argentina, r. Paraná; ANSP 187390, 1, Argentina, r. Paraná; ANSP 187391, 2, Argentina, r. La Plata; ANSP 54124, 2, Uruguay, r. Uruguay; MLP uncat., 5 C\&S, Argentina, r. La Plata; ANSP 172160, 1 C\&S, Brazil, r. São Francisco; MZUSP 78452, 7 SK, Brazil, r. Uruguay; MZUSP 78456, 7 SK, Brazil, r. Uruguay; MZUSP 85624, 2 SK, Brazil, r. São Francisco. Pimelodus microstoma: NMW 45823-45824, Syntypes, ACSI as Pimelodus microstoma, PH (Ribeiro and Lucena, 2007), Brazil, r. Paraná; MZUSP 23204, 1 PH (Ribeiro and Lucena, 2007, Fig. 3), Brazil, r. Paraná. Pimelodus mysteriosus: MLP 9191, Holotype, specimen and PH (Azpelicueta, 1988, figs. 1-3), Argentina, r. Paraná; ANSP 187392, 2, Argentina, r. Paraná; MLP uncat., 1 C\&S, Argentina, r. Paraná; MLP uncat., 3 C\&S, Argentina, r. Paraná; ANSP 180506, 2 SK, Argentina, r. Paraná. Pimelodus navarroi: USNM 121174, Holotype, ACSI as Pimelodus grosskopfii navarroi and PH (Schultz, 1944, pl. 1), Venezuela, L. Maracaibo. Pimelodus ornatus: NMW 45832, 45843, Syntypes, ACSI as Pimelodus ornatus, Suriname, Suriname; Brazil, rio Negro and Cuiabá; MZUSP 34480, Brazil, r. Tapajos; FMNH 53180, 5, Guyana, Tumatumaru; RNMH 25574, 4, Surinam, Surinam r. ANSP 175800, 1, Guyana, Burro Burro r.; ANSP 167655, 1 C\&S, Peru, r. Amazon; DU F1193, 1, SK, Venezuela, r. Apure; ANSP 178542, 1 SK, Peru, r. Amazon; ANSP 180985, 1 SK, Guyana, r. Essequibo. Pimelodus ortmanni: FMNH 54240, Holotype, PH (Garavello and Shibatta, 2007, fig. 1), ACSI as Pimelodus ortmanni, Brazil, r. Iguaçu. Pimelodus paranaensis: MZUSP 23089, Holotype, PH (Britski and Langeani, 1988, figs. 1-2). Brazil, r. Paraná; MZUSP 24454, Paratype, ACSI as Pimelodus ortmanni. Pimelodus pictus: MCZ 7204, Syntype, ACSI as Pimelodus pictus, Peru-Brazil border, r. Hyavary; DU F1012, 65, Venezuela, r. Orinoco; ANSP 160198, 2, Venezuela, r. Orinoco; DU F1012, 1 C\&S, Venezuela, r. Orinoco. Pimelodus platicirris: AMNH 8626, Holotype, Brazil, r. Mogy Guaçu; MZUSP 22489, 2, Brazil, r. Mogy Guaçu; MZUSP 22559, 28, Brazil, r. Mogy Guaçu; AI 228, 1, Brazil, r. Mogy Guaçu; MZUSP 22933, 1 C\&S, Brazil, r. Mogy Guaçu. Pimelodus pohli: MCP 38755, Holotype, PH (Ribeiro and Lucena, 2007, Fig. 1), Brazil, r. São Francisco. Pimelodus punctatus: FMNH 7577, Holotype, Panamá, ACSI as Megalonema punctatum; FMNH 7578, Holotype, Panamá, ACSI as Megalonema robustum. Pimelodus tetramerus: MCP 35809, Holotype, PH (Ribeiro and Lucena, 2006, Fig. 1), Brazil, r. Tocantins; MCP 35830, Paratype, $1 \mathrm{PH}$
(Ribeiro and Lucena, 2006, Fig. 2), Brazil, r. Tocantins; MCP 34514, Paratype, 1 PH (Ribeiro and Lucena, 2006, Fig. 3), Brazil, r. Tocantins. Pimelodus sp.: ANSP 179457 , 6, Peru, Amazon. Pimelodus sp. (as Pimelodus clarias): FMNH 57679, 6, Colombia, r. Magdalena; DU F922, 1,SK, Colombia, r. Magdalena.

Other pimelodids: Bergaria westermani: ZMUC 258, Syntype, Brazil, r. das Velhas; ANSP 172139, 3, Cheirocerus abuelo: MBUCV uncatalogued, 3 SK, Venezuela, L. Maracaibo Basin. Cheirocerus goeldii: MLP uncatalogued, 1 C\&S, Brazil, r. Solimões; ANSP 150162, 1 C\&S, Peru, r., Amazonas. Duopalatinus emarginatus: FMNH 58002, 1, Brazil, r. São Francisco. Duopalatinus peruanus: DU F2004, 1 C\&S, Venezuela, r. Orinoco; ANSP 160189, 1 C\&S, Venezuela, r. Meta. Iheringichthys labrosus: ZMUC 255, Syntype, Argentina, r. de la Plata; MLP uncatalogued, 3 C\&S, Argentina, r. de La Plata. Parapimelodus nigribarbis: MCP 6959, 1 C\&S, Brazil; Parapimelodus valenciennes: ANSP 178800, 4 C\&S, Argentina, r. de La Plata. MCP 12959, 1 C\&S, Brazil.

\section{ACKNOWLEDGMENTS}

For donation or loan of specimens we thank Heraldo Britski and Osvaldo Oyakawa (MZUSP, São Paulo); Julio Garavello (Universidade Federal de São Carlos, São Carlos); Barry Chernoff, Mark Westneat and Mary A. Rogers (FMNH, Chicago), T. Litz (Germany), Carlos Lucena (MCP, Porto Alegre), Jorgen Nielsen (ZMUC, Copenhagen), M. J. P. van Oijen (RMNH, Leiden), and Richard Vari (Smithsonian Institution, Washington). We are most grateful to Kyle Luckenbill (ANSP) for expert preparation of the illustrations, to Mark Sabaj (ANSP) for his assistance with management of specimens, to Sabrina Clavijo for assistance in the field, Daniel Montiel, Director, Dirección Nacional de Recursos Acuáticos, Uruguay, for authorizing collecting permits, and to Carla Pavanelli for information on fresh pigmentation patterns of $P$. heraldoi. Support for travel and publication support was provided by the All Catfish Species Inventory (ACSI, National Science Foundation DEB-0315963) and a research award to JGL (NSF, DEB-0089612); the Argentine Consejo Nacional de Investigaciones Científicas y Técnicas for permanent financial support to MMA.

\section{LITERATURE CITED}

Azpelicueta, M. de las M. 1995. Pimelodus absconditus, a new species of pimelodid catfish from the la Plata Basin (Siluriformes: Pimelodidae). Ichthyological Exploration of Freshwaters, 6 (1): 71-76.

Azpelicueta, M. de las M. 1998. Anew species of Pimelodus 
(Siluriformes: Pimelodidae) from the Paraná and lower Paraná rivers. Neotrópica 44 (11-112): 87-94.

Azpelicueta, M. de las M. 2001. A new species of Pimelodus (Siluriformes: Pimelodidae) from the upper Paraná basin, Brazil. Ichthyological Exploration of Freshwaters, 12 (3): 193-200.

Borodin, N. A. 1927. Pimelodus platicirris, new species and other notes on Brazilian catfishes. American Museum Novitates, 271: 1-4.

Britski,H.A. and F. Langeani. 1988. Pimelodus paranaensis sp. n., um novo Pimelodidae (Pisces, Siluriformes) do Alto Paraná, Brasil. Revista Brasileira Zoologia, 5(3): 409-417.

Garavello, J. C, and O. A. Shibatta. 2007. A new species of the genus Pimelodus La Cépède, 1803 from the rio Iguaçu basin and a reappraisal of Pimelodus ortmanni Haseman, 1911 from the rio Paraná system, Brazil (Ostariophysi: Siluriformes: Pimelodidae). Neotropical Ichthyology, 5(3): 285-292.

Garcia, A. M. and J. P. Vieira. 2001. O aumento da diversidade de peixes no estuário da Lagoa dos Patos durante o episódio El Niño 1997-1998. Atlantica, 23:122-152.

Haseman, J. D. 1911. Some new species of fishes from the Rio Iguassú. Annals of the Carnegie Museum, 7, 374-387, pls. 50, 58, 73-83.

Lundberg, J.G., F. Mago-Leccia and P. Nass. 1991. Exallodontus aguanai, a new genus and species of Pimelodidae (Teleostei: Siluriformes) from deep river channels of South America and delimitation of the sub-family Pimelodinae. Proceedings of the Biological Society Washington. 104(4):840-869.

Lundberg, J. G. and M. W. Littmann. 2003. Family Pimelodidae (Long-whiskered catfishes). p. 432-446. In: R. E. Reis, S. O. Kullander, and C. J. Ferraris (eds.), Cheek list of freshwater fishes of South and
Central Americas, EDIPUCRS, Porto Alegre, Brazil, $603 \mathrm{p}$.

Lütken, C.F. 1874. Siluridae novae Brasiliae centralis a clarissimo J. Reinhardt in provincia Minas-geraës circa oppidulum Lagoa Santa, praecipue in flumine Rio das Velhas et affluentibus collectae, secundum caracteres essentiales, breviter descriptae. Oversigt over Selskabets verksomhed, Kongelige Danske Videnskabernes selskab., Kjobenhavn, 1873, 29-36.

Malabarba, L. R. 1989. Historico Sistematico e Lista Comentada das Especies de Peixes de Agua Doce do Sistema da Laguna dos Patos. Comunicaçoes do Museu de Ciencias da PURCS, Serie Zoologia, v. 2(8):107-179.

Ribeiro, F. R. V. and C. A. S. de Lucena. 2006. A new species of Pimelodus LaCépède, 1803 (Siluriformes: Pimelodidae) from the rio São Francisco drainage, Brazil. Neotropical Ichthyology, 4(4): 411-418.

Ribeiro, F. R. V. and C. A S. de Lucena. 2007. Pimelodus microstoma Steindachner, 1877 a valid species of pimelodid catfish (Siluriformes: Pimelodidae) from the upper rio Paraná drainage. Neotropical Ichthyology 5 (1): 75-78.

Ringuelet, R.A., R.H. and A. Alonso de Aramburu. 1967. Los Peces Argentinos de Agua Dulce. Comisión de Investigación Científica, La Plata. 602 pp.

Schultz, L. P. 1944. The catfishes of Venezuela, with descriptions of thirty-eight new forms. Proceedings of the United States National Museum, 94, 173-338, pls. 1-14.

Steindachner, F. 1877. Die Süsswasserfische des südöstlichen Brasilien, III. Sitzungsberichte der Kaiserlichen Akademie der Wissenschaften, MathematischNaturwissenschaftlichen Classe, Wien, Abt. 1, Botanik, Zoologie, Anatomie, Geologie und Paläontologie, 74, 559-694, pls. 1-13. 